\title{
Pressure effect on crystallization temperature in Zr70Pd30 metallic glass
}

Jiang, Jianzhong; Jeppesen, S; Saida, J.; Lathe, C.

Published in:

Journal of Applied Physics

Link to article, DOI:

$10.1063 / 1.1655684$

Publication date:

2004

Document Version

Publisher's PDF, also known as Version of record

Link back to DTU Orbit

Citation (APA):

Jiang, J., Jeppesen, S., Saida, J., \& Lathe, C. (2004). Pressure effect on crystallization temperature in Zr70Pd30 metallic glass. Journal of Applied Physics, 95(9), 4651-4654. https://doi.org/10.1063/1.1655684

\section{General rights}

Copyright and moral rights for the publications made accessible in the public portal are retained by the authors and/or other copyright owners and it is a condition of accessing publications that users recognise and abide by the legal requirements associated with these rights.

- Users may download and print one copy of any publication from the public portal for the purpose of private study or research.

- You may not further distribute the material or use it for any profit-making activity or commercial gain

- You may freely distribute the URL identifying the publication in the public portal

If you believe that this document breaches copyright please contact us providing details, and we will remove access to the work immediately and investigate your claim. 


\title{
Pressure effect on crystallization temperature in $\mathrm{Zr}_{70} \mathrm{Pd}_{30}$ metallic glass
}

\author{
J. Z. Jiang ${ }^{\text {a) }}$ \\ Department of Materials Science and Engineering, Zhejiang University, Hangzhou 310027, \\ Peoples Republic of China and Department of Physics, Building 307, Technical University of Denmark, \\ DK-2800 Lyngby, Denmark \\ S. Jeppesen \\ Department of Physics, Building 307, Technical University of Denmark, DK-2800 Lyngby, Denmark \\ J. Saida \\ Center for Interdisciplinary Research, Tohoku University, Sendai 980-8578, Japan \\ C. Lathe \\ HASYLAB am DESY, Notkestrasse 85, D-22603 Hamburg, Germany
}

(Received 27 October 2003; accepted 9 January 2004)

The pressure effect on amorphous-to-quasicrystalline-to-intermetallic phase transformations in a $\mathrm{Zr}_{70} \mathrm{Pd}_{30}$ metallic glass has been investigated by in situ $\mathrm{x}$-ray diffraction measurements using synchrotron radiation. It is found that the glass crystallizes in two steps: (1) amorphous-to-icosahedral quasicrystalline and (2) icosahedral quasicrystalline-to-intermetallic $\mathrm{Zr}_{2+x} \mathrm{Pd}$ alloy. The intermetallic alloy has a tetragonal structure with lattice parameters, $a$ $=3.310(1) \AA$ and $c=10.974(1) \AA$, and a space group of I4/mmm. External pressure enhances the onset temperatures for the formation of quasicrystalline phase and intermetallic compound with rates of $11 \pm 3$ and $9 \pm 4 \mathrm{~K} / \mathrm{GPa}$, respectively, while the temperature interval for the stability of quasicrystals remains almost unchanged in the pressure range of $0-3 \mathrm{GPa}$. External pressure does not affect the phase-selection sequence. The enhancement of the onset temperature for the formation of quasicrystals has been further discussed with the nucleation theory. (C) 2004 American Institute of Physics. [DOI: 10.1063/1.1655684]

\section{INTRODUCTION}

Recently, after the discovery of the formation of quasicrystals from $\mathrm{Zr}-\mathrm{Al}-\mathrm{Cu}-\mathrm{Ni}$ metallic glasses, ${ }^{1}$ quasicrystals have been found to form upon crystallization in many $\mathrm{Zr}$ based alloy systems, such as $\mathrm{Zr} M(M=\mathrm{Pd}$ and $\mathrm{Pt}),{ }^{2,3} \mathrm{ZrNi} M$ $(M=\mathrm{Pd}, \mathrm{Au}, \mathrm{Pt}$, and $\mathrm{Ti}),{ }^{4,5} \mathrm{ZrCuM}(\mathrm{Al}$ and $\mathrm{Pd}),{ }^{6,7}$ $\mathrm{ZrAlCuPd},{ }^{7} \mathrm{ZrCuNiPd},{ }^{7} \mathrm{ZrAlNiM}(M=\mathrm{Cu}, \mathrm{Pd}, \mathrm{Au}$, and $\mathrm{Pt}),{ }^{1,8-10} \mathrm{ZrCuTiNi},{ }^{11} \mathrm{ZrAlNiCu} M(M=\mathrm{Ti}, \mathrm{Au}, \mathrm{Pt}, \mathrm{Pd}$, and $\mathrm{Ag}),{ }^{7,12-17} \mathrm{ZrTiCuNiBe},{ }^{18}$ and $\mathrm{ZrTiNbCuNiAl}{ }^{19}$ Furthermore, Inoue and coworkers ${ }^{16}$ found that bulk quasicrystalline ZrAlNiCu $M(M=\mathrm{Pd}$ and $\mathrm{Ag})$ alloys exhibit high strength and good ductility. Hence, the formation of quasicrystals in these alloys becomes very interesting. However, the mechanism of the amorphous-to-quasicrystalline transformation is not completely understood. In the ZrAlNiCuAg system, Chen et al. ${ }^{13}$ suggested a polymorphous transformation while Lee et al. ${ }^{17}$ reported that formation of the quasicrystalline phase may involve partitioning of solutes. Jiang et al. ${ }^{20}{ }^{2}$ suggested that atomic mobility is important for the time-dependent nucleation of quasicrystals in the metallic glass and the authors further revealed changes in quasilattice parameter and composition during the amorphous-toquasicrystalline phase transformation. ${ }^{21}$ The structural stability of the quasicrystals formed in the metallic glass was also reported up to a hydrostatic pressure of $28 \mathrm{GPa}^{22}$ In the

\footnotetext{
a) Author to whom all correspondence should be addressed: electronic mail: jiangjz@zju.edu.cn and jiang@fysik.dtu.dk
}

ZrAlNiCuPd system, Inoue et al. ${ }^{16}$ reported a diffusion controlled amorphous-to-quasicrystalline transformation. In the binary $\mathrm{Zr}_{70} \mathrm{Pd}_{30}$ system, Saida et al. ${ }^{2}$ studied the transformation kinetics by differential scanning calorimetry (DSC) and found that the transformation is also diffusion controlled while Murty et al. ${ }^{3}$ suggested that the composition of the quasicrystals is close to 70 at. \% Zr. Very recently, both groups reported partitioning during the amorphous-toquasicrystalline phase transformation in the alloy. ${ }^{23,24}$ They found that the quasicrystals formed in the $\mathrm{ZrPd}$ system transform into an intermetallic $\mathrm{Zr}_{2} \mathrm{Pd}$ compound at high temperature. Jiang et al. ${ }^{25}$ demonstrated that the amorphous-toquasicrystalline in the $\mathrm{Zr}_{66.7} \mathrm{Pd}_{33.3}$ metallic glass is a polymorphous reaction. Here, we report on the pressure effect on amorphous-to-quasicrystalline-to-intermetallic phase transformations in the $\mathrm{Zr}_{70} \mathrm{Pd}_{30}$ metallic glass by in-situ highpressure and high-temperature $\mathrm{x}$-ray diffraction (XRD) measurements using synchrotron radiation.

\section{EXPERIMENT}

A ribbon sample of the $\mathrm{Zr}_{70} \mathrm{Pd}_{30}$ metallic glass with a cross-section of $0.03 \mathrm{~mm} \times 1 \mathrm{~mm}$ was prepared by the meltspinning technique from a master alloy ingot prepared by arc melting in an Ar atmosphere. The amorphous nature of the as-quenched ribbon was confirmed by $\mathrm{x}$-ray powder diffraction and transmission electron microscopy. Thermal analysis was performed by DSC at a heating rate of $40 \mathrm{~K} / \mathrm{min}$ under a flow of purified argon. 


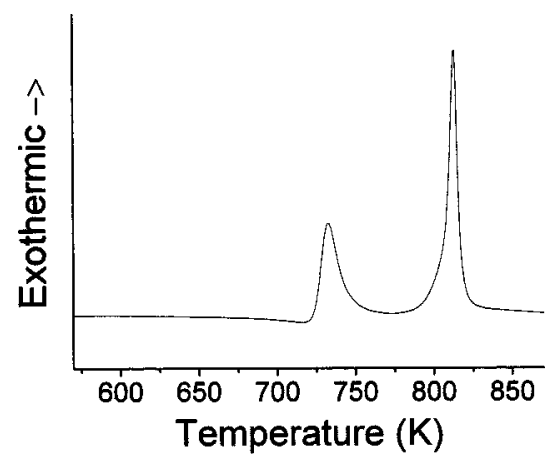

FIG. 1. The DSC curve of the $\mathrm{Zr}_{70} \mathrm{Pd}_{30}$ metallic glass at a heating rate of 40 $\mathrm{K} / \mathrm{min}$ under a flow of purified argon.

In situ high-pressure and high-temperature x-ray diffraction measurements using synchrotron radiation at HASYLAB in Hamburg, Germany, were performed by energydispersive high-pressure $\mathrm{x}$-ray diffraction (EDXRD) at beamline MAX80 using a multianvil pressure apparatus for 5 min exposure of each pattern. ${ }^{26}$ For EDXRD measurements up to about $3 \mathrm{GPa}, 8 \mathrm{~mm}$ cube pressure cells, which were compressed by six truncation anvils of tungsten carbide in a 250-ton hydraulic press, were used. Electric current was sent through a graphite heater via two appropriate anvils. The temperature was measured by means of a thermocouple voltage with a stability of $\pm 1 \mathrm{~K}$. Each run consists of an isothermal room-temperature compression followed by an isobaric heating to high temperature in steps of $10 \mathrm{~K}$. The average heating rate in the temperature range from 298 to $873 \mathrm{~K}$ was roughly estimated to be $3 \mathrm{~K} / \mathrm{min}$. The pressure of the sample is calculated from the lattice constant of $\mathrm{NaCl}$ using the Decker equation of state. ${ }^{27}$ Pure $\mathrm{Zr}$, Fe, and the metallic glass were used to examine possible oxidation of the samples during the heat treatments using the sample assembly. For the three systems, only pure metallic phases were detected after heat treatments at temperatures up to $873 \mathrm{~K}$.

\section{RESULTS AND DISCUSSION}

Figure 1 shows a DSC curve for the $\mathrm{Zr}_{70} \mathrm{Pd}_{30}$ metallic glass. The alloy exhibits an endothermic event characteristic of the glass transition, followed by two characteristic exothermic events indicating a two-stage phase transformation process. It was found that the glass transition temperature $T_{g}$, estimated as the onset temperature of the glass transition event, is $701 \mathrm{~K}$, the onset temperatures and the exothermic heats of the first and second crystallization event, $T_{x 1}$ $=723 \mathrm{~K}, T_{x 2}=799 \mathrm{~K}$, and $21.4 \mathrm{~J} / \mathrm{g}$ and $38.3 \mathrm{~J} / \mathrm{g}$, respectively, $\Delta T=T_{x 1}-T_{g}=22 \mathrm{~K}$, and $T_{x 2}-T_{x 1}=76 \mathrm{~K}$. The structural evolution was further studied by room-temperature XRD for the samples annealed in $1 \times 10^{-4}$ mbar vacuum at 703, 723, and $803 \mathrm{~K}$ for $10 \mathrm{~min}$ using $\mathrm{Cu} \mathrm{K} \alpha$ radiation, as shown in Fig. 2. It is clear that after annealing at $703 \mathrm{~K}$, nanometer-sized quasicrystals are formed in the sample. At $723 \mathrm{~K}$, the intensities of diffraction peaks for the quasicrystalline phase increase while a residual amorphous component still exists. At $803 \mathrm{~K}$, a $\mathrm{Zr}_{2}$ Pd-like phase (tetragonal structure with a space group of $\mathrm{I} 4 / \mathrm{mmm}$ ) is dominant, indicating the quasicrystalline and residual amorphous phases transform to

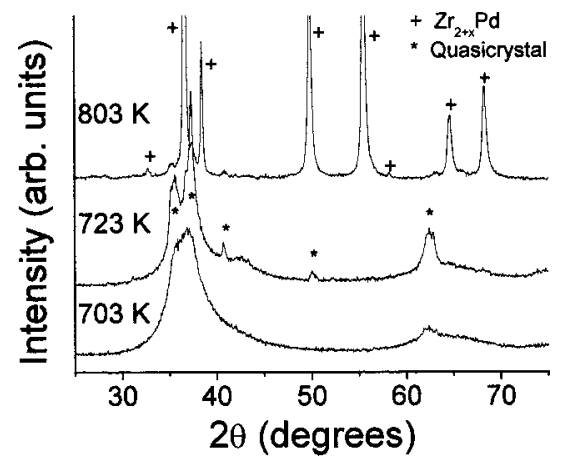

FIG. 2. Room-temperature $\mathrm{x}$-ray powder diffraction patterns recorded for $\mathrm{Zr}_{70} \mathrm{Pd}_{30}$ samples annealed in vacuum $1 \times 10^{-4} \mathrm{mbar}$ at 703,723 , and $803 \mathrm{~K}$ for 10 min using $\mathrm{Cu} \mathrm{K}_{\alpha}$ radiation.

the intermetallic compound. No other crystalline phases were detected with an experimental uncertainty of $3 \%$. We analyzed the diffraction pattern and found the lattice parameters for the intermetallic compound of $a=3.310(1) \AA$ and $c$ $=10.974(1) \AA$. By comparing them with a pure $\mathrm{Zr}_{2} \mathrm{Pd}$ phase, $(a=3.306 \AA$ and $c=10.894 \AA),{ }^{28}$ it is found that the $c$-axis largely expands while the $a$-axis only slightly does. This could be caused by substitution of large-size $\mathrm{Zr}$ atoms on $\mathrm{Pd}$ atomic positions in the tetragonal structure. Thus, the composition of the intermetallic compound might deviate from the stoichiometry to be approximately $\mathrm{Zr}_{2+x} \mathrm{Pd}(x$ $\approx 0.3$ ).

In situ high-temperature EDXRD measurements of the $\mathrm{Zr}_{70} \mathrm{Pd}_{30}$ metallic glass were performed in a pressure range of 0-3 GPa. EDXRD patterns were recorded every $10 \mathrm{~K}$ in order to observe the onset temperature of crystallization within an uncertainty of $10 \mathrm{~K}$. The crystalline phases determined from the EDXRD patterns recorded are identical in the pressure range used. Figure 3 exemplifies EDXRD patterns recorded for the sample at $0.8 \mathrm{GPa}$ and various temperatures. A broad amorphous peak, located at $E \approx 50 \mathrm{keV}$, together with a few Bragg peaks from $\mathrm{BN}$ are observed in the EDXRD patterns recorded at low temperatures up to 703 $\mathrm{K}$. At $713 \mathrm{~K}$, broad Bragg peaks appear and become much clearer in the pattern recorded at $733 \mathrm{~K}$. They are from the quasicrystalline phase. At $753 \mathrm{~K}$ the intermetallic compound

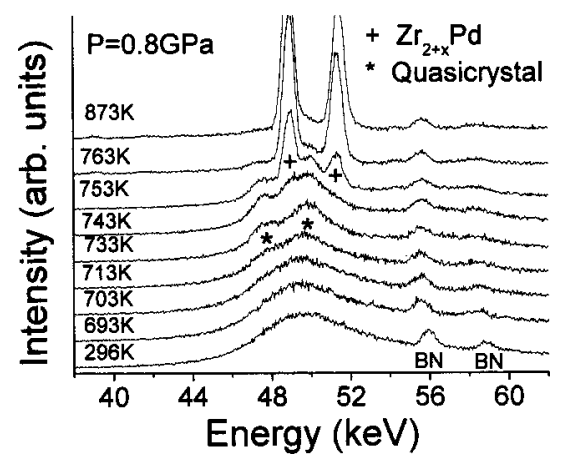

FIG. 3. In situ energy-dispersive $\mathrm{x}$-ray diffraction patterns recorded at 0.8 $\mathrm{GPa}$ for the $\mathrm{Zr}_{70} \mathrm{Pd}_{30}$ metallic glass at various temperatures $(\mathrm{Ed}=121.658$ $\mathrm{keV} \AA$ ). Exposure time is $5 \mathrm{~min}$ for each XRD pattern. Some diffraction peaks of boron nitride originating from the sample holder are marked by $\mathrm{BN}$. 


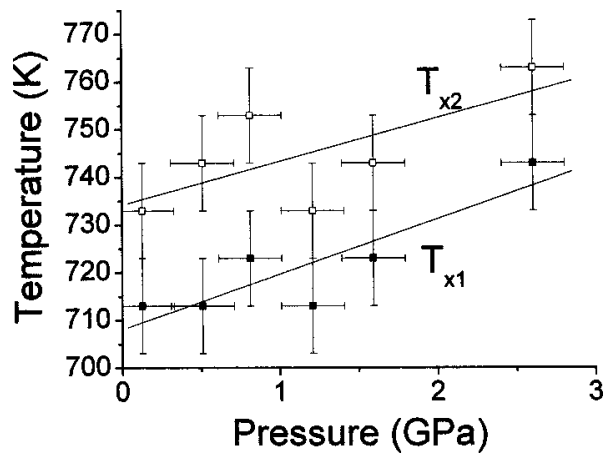

FIG. 4. Onset temperatures for quasicrystalline phase $T_{x 1}$ and intermetallic compound $T_{x 2}$ in the $\mathrm{Zr}_{70} \mathrm{Pd}_{30}$ metallic glass as a function of pressure. The solid lines represent the linear fit to the data.

appears while at $873 \mathrm{~K}$ only the intermetallic compound was detected. Figure 4 shows the onset temperatures for quasicrystalline phase, $T_{x 1}$, and for intermetallic compound $T_{x 2}$, as a function of pressure. It is clear that $T_{x 1}$ and $T_{x 2}$ increase with pressure having slopes of $11 \pm 3$ and $9 \pm 4 \mathrm{~K} / \mathrm{GPa}$, respectively. The slopes obtained here are similar to literature data reported for metallic glasses with a wide supercooled liquid region, e.g., $19 \mathrm{~K} / \mathrm{GPa}$ for the $\mathrm{Zr}_{41.2} \mathrm{Ti}_{13.8} \mathrm{Cu}_{12.5} \mathrm{Ni}_{10} \mathrm{Be}_{22.5}$ bulk glass ${ }^{29}$ in the pressure range of $0-4 \mathrm{GPa}, 30 \mathrm{~K} / \mathrm{GPa}$ for the $\mathrm{Fe}_{72} \mathrm{P}_{11} \mathrm{C}_{6} \mathrm{Al}_{5} \mathrm{~B}_{4} \mathrm{Ga}_{2}$ glass ${ }^{26}$ in the pressure range of $0-2.4 \mathrm{GPa}, 11 \mathrm{~K} / \mathrm{GPa}$ for the $\mathrm{Pd}_{40} \mathrm{Cu}_{30} \mathrm{Ni}_{10} \mathrm{P}_{20}$ bulk glass ${ }^{30}$ in the pressure range of $0-4$ GPa, 9.5 K/GPa for the $\mathrm{Zr}_{48} \mathrm{Nb}_{8} \mathrm{Cu}_{14} \mathrm{Ni}_{12} \mathrm{Be}_{18}$ bulk glass ${ }^{31}$ in the range of $0-4.4 \mathrm{GPa}$, and $16 \mathrm{~K} / \mathrm{GPa}$ for the $\mathrm{Mg}_{60} \mathrm{Cu}_{30} \mathrm{Y}_{10}$ bulk glass in the pressure range $0-4 \mathrm{GPa}^{32}$ Note that the crystallization temperatures deduced from DSC and XRD are slightly different, which could be due to (1) different heating rates used and (2) different techniques used.

For the crystallization process in the $\mathrm{Zr}_{70} \mathrm{Pd}_{30}$ metallic glass, the onset temperature of the amorphous-toquasicrystalline phase transformation may be governed by the thermodynamic potential energy barrier of nucleation. According to crystallization kinetics theory, the nucleation rate $I$ can be written as $I=I_{0} / \exp \left(\left(\Delta G^{*}+Q_{n}\right) / k_{\mathrm{B}} T\right)$, where $I_{0}$ is a constant, $k_{B}$ is Boltzmann's constant, $Q_{n}$ is the activation energy for the transport of an atom across the interface of an embryo, and $\Delta G^{*}$ is the free energy required to form a nucleus of the critical size, i.e., the thermodynamic potential energy barrier of nucleation, $\Delta G^{*} \propto 1 /(P \Delta V+\Delta G)^{2}$, where $\Delta V$ and $\Delta G$ are the changes of molar volume and free energy from amorphous to quasicrystalline phase. The sum, $\Delta G^{*}+Q_{n}$, is called the nucleation work. In general, pressure could reduce atomic mobility. This means that $Q_{n}$ might increase with pressure. Based on the observation in Fig. 2, it is not unreasonable to expect $\Delta G=G_{\text {quasi }}-G_{\text {amor }}<0$. Moreover, Holzer and Kelton ${ }^{33}$ reported that the densities of the amorphous and quasicrystalline $\mathrm{Al}_{75} \mathrm{Cu}_{15} \mathrm{~V}_{10}$ phase are 3.92 \pm 0.04 and $3.79 \pm 0.06 \mathrm{~g} / \mathrm{cm}^{3}$, respectively. Their result indicates a larger molar volume for the quasicrystalline phase than the corresponding amorphous phase. Assuming the same behavior for the $\mathrm{Zr}_{70} \mathrm{Pd}_{30}$ metallic glass, $\Delta V=V_{\text {quasi }}$ $-V_{\text {amor }}>0,(P \Delta V+\Delta G)^{2}$ could be smaller than $(\Delta G)^{2}$ with increasing pressure from ambient condition to $3 \mathrm{GPa}$.
Consequently, the external pressure applied enhances the thermodynamic potential energy barrier of nucleation. Hence, the nucleation work increases with pressure. Consequently, it is expected that the onset temperature of the amorphous-to-quasicrystalline phase transformation in the $\mathrm{Zr}_{70} \mathrm{Pd}_{30}$ metallic glass increases with pressure, as observed in Fig. 4. For the quasicrystalline-to-intermetallic phase transition, $\Delta G^{*}$ should decrease with pressure because of negative $\Delta V$ and $\Delta G$. However, we experimentally observed an increase of $T_{x 2}$ with pressure. This means that the nucleation work increases with pressure, which indicates that $Q_{n}$, which is dominant, might increase with pressure.

\section{CONCLUSIONS}

In conclusion, the pressure effect of the amorphous-toquasicrystalline-to-intermetallic phase transformations in the $\mathrm{Zr}_{70} \mathrm{Pd}_{30}$ metallic glass has been investigated by in situ $\mathrm{x}$-ray diffraction measurements using synchrotron radiation. It is found that external pressure does not affect the phaseselection sequence. But, it enhances the onset temperatures for the formation of quasicrystalline phase and intermetallic compound with rates of $11 \pm 3$ and $9 \pm 4 \mathrm{~K} / \mathrm{GPa}$, respectively, while the temperature interval for the stability of quasicrystals remains almost unchanged in the pressure range of $0-3$ $\mathrm{GPa}$.

\section{ACKNOWLEDGMENTS}

The authors would like to thank HASYLAB in Hamburg, MAXlab in Lund, and Spring8 in Japan for use of the synchrotron radiation facilities. Financial support from Zhejiang University, the National Natural Science Foundation of China (No. 50341032), the Danish Technical Research Council, and the Danish Natural Sciences Research Council through DANSYNC is gratefully acknowledged.

${ }^{1}$ U. Köster, J. Meinhardt, S. Roos, and H. Liebertz, Appl. Phys. Lett. 69, 179 (1996); U. Köster, J. Meinhardt, S. Roos, and A. Rudiger, Mater. Sci. Forum 225, 311 (1996).

${ }^{2}$ J. Saida, M. Matsushita, and A. Inoue, Appl. Phys. Lett. 77, 73 (2000); J. Appl. Phys. 88, 6081 (2000); 90, 4717 (2001).

${ }^{3}$ B. S. Murty, D. H. Ping, and K. Hono, Appl. Phys. Lett. 77, 1102 (2000).

${ }^{4}$ J. Saida, M. Matsushita, C. Li, and A. Inoue, Appl. Phys. Lett. 76, 3558 (2000).

${ }^{5}$ S. Yi and D. H. Kim, J. Mater. Res. 15, 892 (2000).

${ }^{6}$ B. S. Murty, D. H. Ping, K. Hono, and A. Inoue, Appl. Phys. Lett. 76, 55 (2000).

${ }^{7}$ B. S. Murty, D. H. Ping, K. Hono, and A. Inoue, Scr. Mater. 43, 103 (2000).

${ }^{8}$ U. Köster, J. Meinhardt, S. Roos, and R. Busch, Mater. Sci. Eng., A 226, 995 (1997); D. Zander, R. Janlewing, A. Rüdiger, and U. Köster, Mater. Sci. Forum 307, 25 (1999).

${ }^{9}$ A. Inoue, J. Saida, M. Matsushita, and T. Sakurai, Mater. Trans., JIM 41, 362 (2000).

${ }^{10}$ J. Eckert, N. Mattern, M. Zinkevitch, and M. Seidel, Mater. Trans., JIM 39, 623 (1998).

${ }^{11}$ D. V. Louzguine and A. Inoue, Appl. Phys. Lett. 78, 1841 (2001).

${ }^{12}$ L. Q. Xing, J. Eckert, W. Löser, and L. Schultz, Appl. Phys. Lett. 73, 2110 (1998); 74, 664 (1999).

${ }^{13}$ M. W. Chen, T. Zhang, A. Inoue, A. Sakai, and T. Sakurai, Appl. Phys. Lett. 75, 1697 (1999).

${ }^{14}$ A. Inoue, T. Zhang, J. Saida, M. Matsushita, M. W. Chen, and T. Sakurai, Mater. Trans., JIM 40, 1137 (1999); 40, 1181 (1999).

${ }^{15}$ J. Saida, M. Matsushita, T. Zhang, A. Inoue, M. W. Chen, and T. Sakurai, Appl. Phys. Lett. 75, 3497 (1999). 
${ }^{16}$ A. Inoue, T. Zhang, M. W. Chen, T. Sakurai, J. Saida, and M. Matsushita, Appl. Phys. Lett. 76, 967 (2000).

${ }^{17}$ J. K. Lee, G. Choi, D. H. Kim, and W. T. Kim, Appl. Phys. Lett. 77, 978 (2000).

${ }^{18}$ N. Wanderka, M.-P. Macht, M. Seidel, S. Mechler, K. Ståhl, and J. Z. Jiang, Appl. Phys. Lett. 77, 3935 (2000).

${ }^{19}$ U. Kühn, J. Eckert, N. Mattern, and L. Schultz, Appl. Phys. Lett. 77, 3176 (2000).

${ }^{20}$ J. Z. Jiang, Y. X. Zhuang, H. Rasmussen, J. Saida, and A. Inoue, Phys. Rev. B 64, 094208 (2001).

${ }^{21}$ J. Z. Jiang, A. R. Rasmussen, C. H. Jensen, Y. Lin, and P. L. Hansen, Appl. Phys. Lett. 80, 2090 (2002).

${ }^{22}$ J. Z. Jiang, K. Saksl, H. Rasmussen, T. Watanuki, N. Ishimatu, and O. Shimomara, Appl. Phys. Lett. 79, 1112 (2001).

${ }^{23}$ J. Saida, M. Matsushita, and A. Inoue, J. Appl. Phys. 90, 4717 (2001).

${ }^{24}$ B. S. Murty, D. H. Ping, M. Ohnuma, and K. Hono, Acta Mater. 49, 3453 (2001).

${ }^{25}$ J. Z. Jiang, K. Saksl, J. Saida, A. Inoue, H. Franz, K. Messel, and C. Lathe, Appl. Phys. Lett. 80, 781 (2002).
${ }^{26}$ J. Z. Jiang, J. S. Olsen, L. Gerward, S. Abdali, J. Eckert, N. Schlorke, L. Schultz, J. Truckenbrodt, and P. X. Shi, J. Appl. Phys. 87, 2664 (2000); J. S. Olsen, L. Gerward, and J. Z. Jiang, J. Phys. Chem. Solids 60, 229 (1999).

${ }^{27}$ D. L. Decker, J. Appl. Phys. 42, 3239 (1971).

${ }^{28}$ JCPDS-International Centre for Diffraction Data, 1601 Park Lane, Swathmore, PA, (1998), $\mathrm{Zr}_{2} \mathrm{Pd}$ compound, No. 18-0962.

${ }^{29}$ J. Z. Jiang, T. J. Zhou, H. K. Rasmussen, U. Kühn, J. Eckert, and C. Lathe, Appl. Phys. Lett. 77, 3553 (2000).

${ }^{30}$ J. Z. Jiang, Y. X. Zhuang, H. Rasmussen, N. Nishiyama, A. Inoue, and C. Lathe, Europhys. Lett. 54, 182 (2001).

${ }^{31}$ Y. X. Zhuang, L. Gerward, J. Z. Jiang, J. S. Olsen, Y. Zhang, and W. H. Wang, Mater. Res. Soc. Symp. Proc. 644, L5.2.1 (2001).

${ }^{32}$ S. Linderoth, N. Pryds, M. Eldrup, A. S. Pedersen, M. Ohnuma, T. J. Zhou, L. Gerward, J. Z. Jiang, and C. Lathe, Mater. Res. Soc. Symp. Proc. 644, L4.1.1 (2001).

${ }^{33}$ J. C. Holzer and K. F. Kelton, Acta Metall. Mater. 39, 1833 (1991). 